\title{
Soil Nutrient and Crop Growth Dynamics in Organically Managed Cropping System
}

\author{
Vishaw Vikas ${ }^{1 *}$, A.K. Mondal ${ }^{1}$, Vikas Sharma ${ }^{1}$ and Jag Paul Sharma ${ }^{2}$ \\ ${ }^{1}$ Division of Soil Science \& Agricultural Chemistry, SKUAST Jammu, India \\ ${ }^{2}$ Directorate of Research, SKUAST Jammu, India \\ *Corresponding author
}

Keywords

Available Nitrogen,

Available

Phosphorus,

Available

Potassium, Yield,

Curd Weight

Article Info

Accepted:

05 January 2020

Available Online:

10 February 2020

A B S T R A C T

A study was conducted at Organic Farming Research Centre, SKUAST J in which focus was to analyze the impact of organic manures on soil nutrient availability and crop growth dynamics in legume based cropping system. In the experiment, it was found that from 2016 to 2017, available nitrogen in soil depicted significant results as values followed a variable pattern. Change noted with highest to lowest value observed $285.8 \mathrm{~kg} \mathrm{ha}^{-1}$ to $252.9 \mathrm{~kg} \mathrm{ha}^{-1}$. Available phosphorus was found to be significant as very positive change was observed compared to control. Highest value $21.44 \mathrm{~kg}$ $\mathrm{ha}^{-1} \mathrm{P}$ was noted in $\mathrm{T}_{8}$ in experiment. Available Potassium values in soil were found to be non-significant as minor variations in treatments were observed as compared to control. During $1^{\text {st }}$ and $2^{\text {nd }}$ year of experiment, significant improvement in crop yield and curd weight was observed in Okra and Broccoli as compared to control. The maximum okra yield and curd weight observed was $146.32 \mathrm{q} \mathrm{ha}^{-1}$ in $\mathrm{T}_{8}$ and $314.33 \mathrm{gms}$ in $\mathrm{T}_{8}$ in 2017.

\section{Introduction}

Climate change isa major issue worldwide as struggle to tackle the problem continues despite severe efforts and precautions to control which is not affecting much to reduce emissions. However, agricultural science has responded well to the world's call to control and analyze the climate change in a sustainable way. Organic farming has framed some new aspects and trends to visualize and optimize the concept of soil sustainability, soil health and productivity.

The uses of organic and green manures have led to the study of new dynamics in soil and crop study. Organically managed farms are not only eco-friendly but are also sustainable 
in every aspect. Deputation of legumes along with animal manures is now proven to provide an outstanding response in terms of nutrient dynamics and yield and the same has been proven by many researchers worldwide (Larson and Clapp, 1984; Doran and Parkin, 1994 and Sudha and Chandini, 2003) as the conversion of manures to biomass has improved the fertility and soil in almost every aspect.

Now, organic manures have been accepted as an alternate towards chemical fertilizers in vegetable cropping patterns and their usage is increasing with awareness. (Barik et al., 2006 and Savoshi et al., 2011).

The researchers all around the world has pointed that organic farming plays a significant role in sustainable agriculture, since Jammu falls in sub-tropical zone may contain low organic matter content and highly disturbed soils due to excessive cultivation practices and uncalculated dosage of chemical fertilizers and rapid decomposition of organic matter may be rapid due to high temperatures (Pholsen, 2003; Kasikranan, 2003) in most of the months.
Such problem on soil deterioration should urgently be addressed. So, the benefits of organic implications on food quality and safety have created high global consumption for organic products and utilization of organic wastes as organic fertilizer for growing crops commercially is very much dependent on the availability of organic wastes.

So, to analyze the impact of organic manures on soil quality, a study was conducted at Organic Farming Research Centre, SKUAST Jammu in which main objective was to understand soil available nitrogen, phosphorus and crop growth dynamics in organically managed legume based cropping system.

\section{Materials and Methods}

The study was conducted at Organic Farming Research Centre of SKUAST -Jammu during 2016-17 and 2017-18.Geographically the experimental site is located at $32^{\circ} 39^{\prime} 35.5^{\prime \prime} \mathrm{N}$ latitude and $74^{\circ} 47^{\prime} 35.0^{\prime \prime} \mathrm{E}$ longitude at an elevation of 332 meters above the mean sea level in site the Shivalik foothill plains of North-Western Himalayas. The analysis was done post-harvest of crops.

Table.1 Initial values of soil of pre-experimental field

\begin{tabular}{|c|c|}
\hline Physical Properties & Initial Values \\
\hline Soil Organic Carbon $\left(\mathrm{g} \mathrm{kg}^{-1}\right)$ & 6.27 \\
\hline Available Nitrogen $\left(\mathrm{kg} \mathrm{ha}^{-1}\right)$ & 247.2 \\
\hline Available Phosphorus (kg ha $\left.{ }^{-1}\right)$ & 13.95 \\
\hline Available Potassium $\left(\mathrm{kg} \mathrm{ha}^{-1}\right)$ & 236.1 \\
\hline Particle Size Analysis (Texture): Sandy Clay Loam & $\begin{array}{c}\text { Sand- } 54.22 \\
\text { Silt- } 15.82 \\
\text { Clay- } 29.96\end{array}$ \\
\hline
\end{tabular}


Table. 2 Treatment details

\begin{tabular}{|c|l|c|}
\hline Treatments & \multicolumn{1}{|c|}{ Input } & Qty. applied tonne ha ${ }^{-\mathbf{1}}$ \\
\hline $\mathbf{T}_{\mathbf{1}}$ & No application & Nil \\
\hline $\mathbf{T}_{\mathbf{2}}$ & Farm Yard Manure & 10.00 \\
\hline $\mathbf{T}_{\mathbf{3}}$ & Vermicompost & 6.60 \\
\hline $\mathbf{T}_{\mathbf{4}}$ & Poultry Manure & 2.91 \\
\hline $\mathbf{T}_{\mathbf{5}}$ & Neem Cake & 2.00 \\
\hline $\mathbf{T}_{\mathbf{6}}$ & Farm Yard Manure + Poultry Manure & $5+1.45$ \\
\hline $\mathbf{T}_{\mathbf{7}}$ & Farm Yard Manure + Neem Cake & $5+1.00$ \\
\hline $\mathbf{T}_{\mathbf{8}}$ & Vermicompost + Poultry Manure & $3.30+1.45$ \\
\hline $\mathbf{T}_{\mathbf{9}}$ & Vermicompost + Neem Cake & $3.30+1.00$ \\
\hline $\mathbf{T}_{\mathbf{1 0}}$ & Neem Cake + Poultry Manure & $1.00+1.45$ \\
\hline
\end{tabular}

*Blanket application of FYM @ 10.00tonneha ${ }^{-1}$ was done

Table.3 Analytical methods employed in soil sample analysis for soil organic carbon and soil physical properties

\begin{tabular}{|c|l|c|c|}
\hline S.No. & \multicolumn{1}{|c|}{ Parameter } & Method & Source \\
\hline $\mathbf{1}$ & Soil Texture & International Pipette Method & Piper (1966) \\
\hline $\mathbf{2}$ & Soil Organic Carbon & $\begin{array}{c}\text { Chromic acid wet digestion } \\
\text { method }\end{array}$ & Walkley and Black (1934) \\
\hline $\mathbf{3}$ & Available Nitrogen & $\begin{array}{c}\text { Alkaline permanganate } \\
\text { method }\end{array}$ & Subbiah and Asija(1956) \\
\hline $\mathbf{4}$ & Available Phosphorus & $\begin{array}{c}\text { Olsen method using } \\
\text { colorimeter }\end{array}$ & Olsen et al., (1954) \\
\hline $\mathbf{5}$ & Available Potassium & Flame photometric method & Stanford and English (1949) \\
\hline
\end{tabular}

\section{Statistical analysis}

The data on various characters studied during the course of investigation were statistically analyzed by using Tukey's test with an aim to figure out which groups in our sample differ by using "Honest Significant Difference," a number that represents the distance between groups, to compare every mean with every other mean.

\section{Results and Discussion}

The outcome observed in present study as well as discussion has been summarized under following heads:

\section{Available Nitrogen}

In 2016 to 2017, available nitrogen in soil depicted significant results as values followed a variable pattern (Table 4). Change noted with highest to lowest value observed $285.8 \mathrm{~kg}$ $\mathrm{ha}^{-1}$ to $252.9 \mathrm{~kg} \mathrm{ha}^{-1}$. Highest average available nitrogen value $283.5 \mathrm{~kg} \mathrm{ha}^{-1}$ was observed in $\mathrm{T}_{8}$ (Vermicompost + poultry manure)and was considered best performing treatment. A study by Moyin-Jesu and Atoyosoye (2002); and Adekayode (2010) depicts that poultry manure and vermicompost being the high accumulator of $\mathrm{N}, \mathrm{P}, \mathrm{K}$ and moderate $\mathrm{Ca}$ and $\mathrm{Mg}$ showed the best performance in terms of soil fertility. 
The research results also agreed with Babalo et al., (2000) who reported that poultry manure when applied to soil has the tendency to stimulate the microbial activity and thereby enhance the release of organic nitrogen and phosphorus in soil.

Along with this, there are many researches in science world that depicts higher soil nitrogen and phosphorus in organically treated soils. (Simek et al., 1999; Saviozzi et al., 1999). Also, certain concentrated organic manures like poultry manure have the ability to cause the net mobilization of soil nitrogen Murwira and Kirchrnann, 1993).

Statistical analysis in the experiment showed significant increase in nitrogen and phosphorus which was in agreement with the statement of Dikinya and Mufwanzala (2010) who also observed an increase in available nitrogen content in soil after the addition of poultry and associated manures. Also, the presence of higher nitrogen content in FYM, poultry manure and vermicompost has led to an increased fraction of soil organic matter and biomass (Fig. 1).

Similar findings were also reported by Amanullah et al., 2006 and Prasanthrajan et al., 2008. The incorporation of Dhaincha into the soil increased the plant available nitrate $\mathrm{N}$ and more mineral $\mathrm{N}$ from residues of legumes (Dalal et al., 1998 and Pilbeam et al., 1998).

Thus it is understandable that inclusion of legume in vegetable cropping patterns can lead to increase in soil nitrogen (Ahmed et al., 2001); however in the experiment there was $13.00 \%$ increase in soil available nitrogen in 2017 as compared to control in 2016.

\section{Available Phosphorus}

The values related to soil available phosphorus are presented in Table 5. As per tukey's post- hoc analysis, available phosphorus was found to be significant in year 2016 and 2017 as very positive change was observed as compared to control. Significant results were obtained with highest value $21.44 \mathrm{~kg} \mathrm{ha}^{-1}$ was noted in $\mathrm{T}_{8}$ in experiment as compared to control $\mathrm{T}_{1}$ which was $15.98 \mathrm{~kg} \mathrm{ha}^{-1}$.

Statistical analysis explained that the significant increase in $\mathrm{P}$ concentration in soil was due to the application of combination of organic manure (Vermicompost + Poultry Manure) which was in agreement with studies of Adejoro, 2005; Davis et al., 2006 where P improvement was found significant by application of poultry manure and associated manures (Fig. 2).

The application of organic manures have significantly reduced the fixation of added $\mathrm{P}$ as well as native P, making it more available to the plant because of the reaction of intermediate compounds with phosphatefixing cations such as $\mathrm{Al}^{3+}, \mathrm{Fe}^{3+}$ etc., thereby reducing $\mathrm{P}$ adsorption capacity (Ghosh et al., 1981; Son and Ramaswami, 1997).

Similarly, the application of organic phosphorus has led to increase in labile $\mathrm{P}$ through complexing of cations like $\mathrm{Ca}^{2+}$ and $\mathrm{Mg}^{2+}$ responsible for $\mathrm{P}$ fixation has been reported by Balaguravaiah et al., 2005. Also, Gupta et al., 1988 reported that organic manures have the tendency to reduce the activity of polyvalent cations such as $\mathrm{Ca}^{2+}$, $\mathrm{Fe}^{3+}$ and $\mathrm{Al}^{3+}$ due to chelation which in turn is highly responsible for reduction in fixation of P.

Therefore there was improvement in phosphorus availability with the application of organic manures and it was similar with the findings of Chithesh 2005. In the experiment there was significant rise in available phosphorus by $34.16 \%$ at the end of experiment in 2017. 


\section{Available Potassium}

Available Potassium values in soil were found to be non-significant as minor variations in treatments were observed as compared to control (Table 6). The maximum potassium observed was $237.8 \mathrm{~kg} \mathrm{ha}^{-1}$ in $\mathrm{T}_{1}$ in 2016; however after then it consistently decreased with continuation of experiment which can be related to higher depletion of potassium by green manure and vegetable crops as reported by Bariket al., 2006.

Also, another reason can be the ratio of application to consumption might have gone low as removal of potassium by crops might have exceeded the incorporation. The lack of crop ability to extract $\mathrm{K}$ from another form of soil $\mathrm{K}$ can also be another reason of lowering of available K (Sudhakar, 2000).

The medium content of potassium in soil in pre-experimental field and lack of supplement through external sources can also be a reason of consistently lowering of soil available potassium in experiment (Elangovan, 1984). In this two year experiment, the available potassium loss was greater than $5 \%$ with lowest value observed at the end of experiment.

Fig.1 Relationship between Soil Organic Carbon and Soil Available Nitrogen was found positively correlated in $2016\left(R^{2}=0.88\right)$ and $2017\left(R^{2}=0.85\right)$

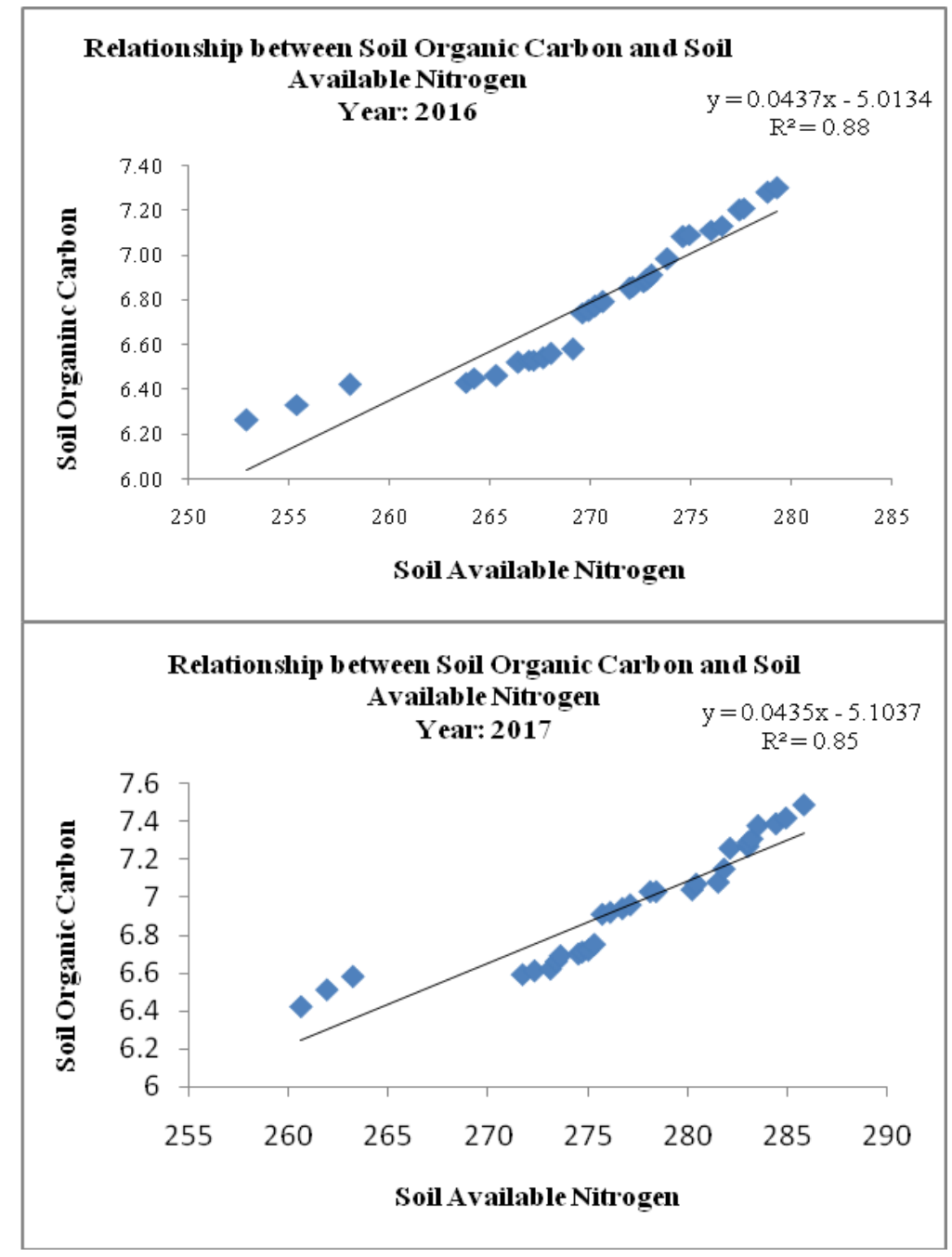


Fig.2 Relationship between Soil Organic Carbon and Soil Available Phosphorus was found positively correlated in $2016\left(\mathrm{R}^{2}=0.79\right)$ and $2017\left(\mathrm{R}^{2}=0.96\right)$

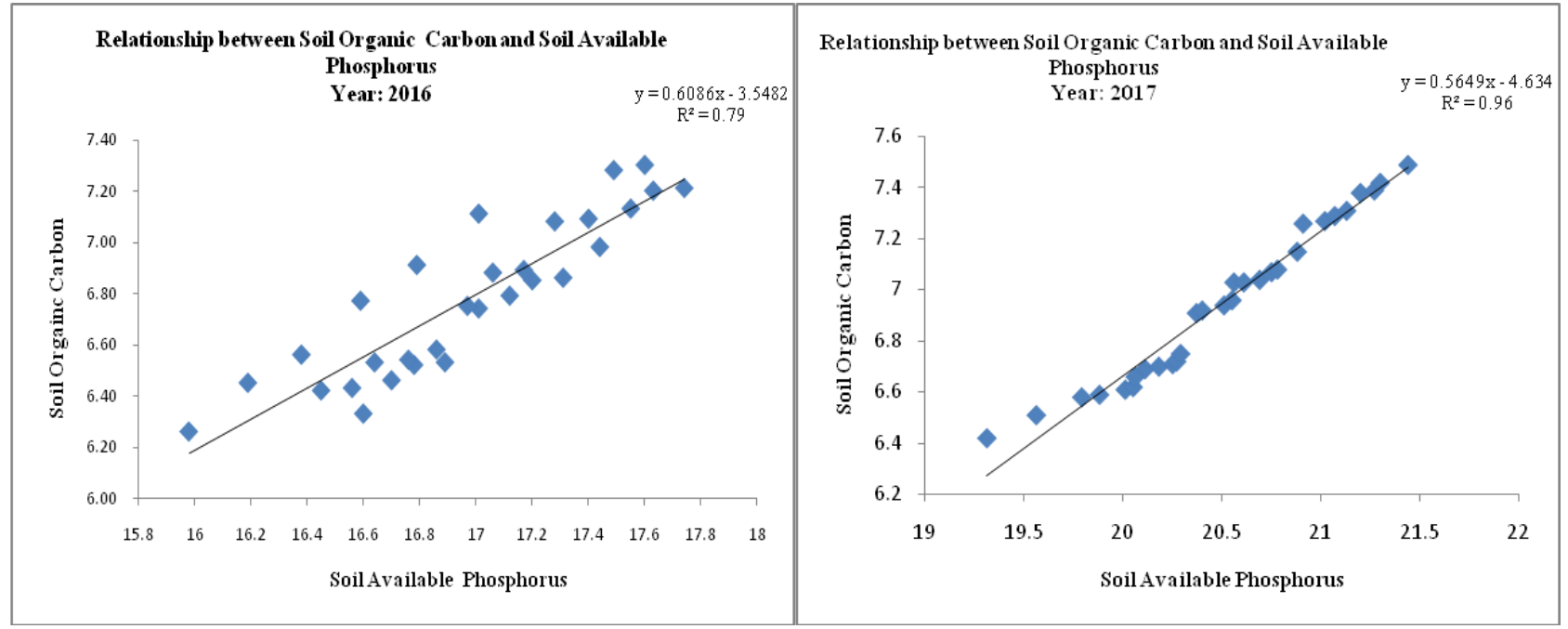

Table.4 Impact of organic manures on Available Nitrogen $\left(\mathrm{kg} \mathrm{ha}^{-1}\right)$ post-harvest soils

\begin{tabular}{|l|c|c|c|c|c|c|c|c|c|}
\hline \multicolumn{1}{|c|}{ N } & \multicolumn{3}{|c|}{ Okra } & \multicolumn{3}{c|}{ Dhaincha } & \multicolumn{3}{c|}{ Broccoli } \\
\hline \multicolumn{1}{|c|}{ Treatment } & 2016 & 2017 & Mean & 2016 & 2017 & Mean & 2016 & 2017 & Mean \\
\hline T1: Control & $252.9^{\mathrm{a}}$ & $260.6^{\mathrm{a}}$ & $256.7^{\mathrm{a}}$ & $255.4^{\mathrm{a}}$ & $263.2^{\mathrm{a}}$ & $259.3^{\mathrm{a}}$ & $258.0^{\mathrm{a}}$ & $261.9^{\mathrm{a}}$ & $261.9^{\mathrm{a}}$ \\
\hline T2: FYM & $264.2^{\mathrm{b}}$ & $272.3^{\mathrm{b}}$ & $268.2^{\mathrm{b}}$ & $266.9^{\mathrm{b}}$ & $275.0^{\mathrm{b}}$ & $270.9^{\mathrm{b}}$ & $269.6^{\mathrm{b}}$ & $273.6^{\mathrm{b}}$ & $273.6^{\mathrm{b}}$ \\
\hline T3: VC & $265.3^{\mathrm{b}}$ & $273.4^{\mathrm{b}}$ & $269.3^{\mathrm{b}}$ & $268.0^{\mathrm{b}}$ & $276.1^{\mathrm{b}}$ & $272.0^{\mathrm{b}}$ & $270.6^{\mathrm{b}}$ & $274.7^{\mathrm{b}}$ & $274.7^{\mathrm{b}}$ \\
\hline T4: PM & $267.2^{\mathrm{b}}$ & $275.3^{\mathrm{b}}$ & $271.3^{\mathrm{b}}$ & $269.9^{\mathrm{b}}$ & $278.1^{\mathrm{b}}$ & $274.0^{\mathrm{b}}$ & $272.6^{\mathrm{b}}$ & $276.7^{\mathrm{b}}$ & $276.7^{\mathrm{b}}$ \\
\hline T5: NC & $263.8^{\mathrm{b}}$ & $271.7^{\mathrm{b}}$ & $267.8^{\mathrm{b}}$ & $266.4^{\mathrm{b}}$ & $274.5^{\mathrm{b}}$ & $270.4^{\mathrm{b}}$ & $269.1^{\mathrm{b}}$ & $273.1^{\mathrm{b}}$ & $273.1^{\mathrm{b}}$ \\
\hline T6: FYM + PM & $272.8^{\mathrm{c}}$ & $281.5^{\mathrm{c}}$ & $276.6^{\mathrm{c}}$ & $276.0^{\mathrm{c}}$ & $284.4^{\mathrm{c}}$ & $280.2^{\mathrm{c}}$ & $278.8^{\mathrm{b}}$ & $283.0^{\mathrm{c}}$ & $280.9^{\mathrm{c}}$ \\
\hline T7: FYM + NC & $272.1^{\mathrm{b}}$ & $280.4^{\mathrm{c}}$ & $276.3^{\mathrm{c}}$ & $274.9^{\mathrm{c}}$ & $283.2^{\mathrm{c}}$ & $279.0^{\mathrm{c}}$ & $277.6^{\mathrm{b}}$ & $281.8^{\mathrm{c}}$ & $281.8^{\mathrm{c}}$ \\
\hline T8: VC + PM & $273.8^{\mathrm{c}}$ & $282.1^{\mathrm{c}}$ & $277.9^{\mathrm{c}}$ & $276.5^{\mathrm{c}}$ & $284.9^{\mathrm{c}}$ & $280.7^{\mathrm{c}}$ & $279.3^{\mathrm{b}}$ & $283.5^{\mathrm{c}}$ & $283.5^{\mathrm{c}}$ \\
\hline T9: VC + NC & $267.6^{\mathrm{b}}$ & $275.7^{\mathrm{b}}$ & $271.6^{\mathrm{b}}$ & $270.2^{\mathrm{b}}$ & $278.4^{\mathrm{b}}$ & $274.3^{\mathrm{b}}$ & $273.0^{\mathrm{b}}$ & $277.1^{\mathrm{b}}$ & $277.1^{\mathrm{b}}$ \\
\hline T10: NC + PM & $271.9^{\mathrm{c}}$ & $280.2^{\mathrm{c}}$ & $276.0^{\mathrm{c}}$ & $274.6^{\mathrm{c}}$ & $283.0^{\mathrm{c}}$ & $278.8^{\mathrm{c}}$ & $277.4^{\mathrm{b}}$ & $285.8^{\mathrm{c}}$ & $281.6^{\mathrm{c}}$ \\
\hline
\end{tabular}

*Mean values with single alphabet are statistically significant 
Table.5 Impact of organic manures on Available Phosphorus $\left(\mathrm{kg} \mathrm{ha}^{-1}\right)$ post-harvest soils

\begin{tabular}{|l|c|c|c|c|c|c|c|c|c|}
\hline \multicolumn{1}{|c|}{ P } & \multicolumn{3}{|c|}{ Okra } & \multicolumn{3}{c|}{ Dhaincha } & \multicolumn{3}{c|}{ Broccoli } \\
\hline \multicolumn{1}{|c|}{ Treatment } & $\mathbf{2 0 1 6}$ & $\mathbf{2 0 1 7}$ & Mean & $\mathbf{2 0 1 6}$ & 2017 & Mean & 2016 & 2017 & Mean \\
\hline T1: Control & $15.98^{\mathrm{a}}$ & $19.31^{\mathrm{a}}$ & $17.64^{\mathrm{a}}$ & $16.38^{\mathrm{a}}$ & $19.79^{\mathrm{a}}$ & $7.65^{\mathrm{a}}$ & $16.79^{\mathrm{a}}$ & $20.29^{\mathrm{a}}$ & $18.54^{\mathrm{a}}$ \\
\hline T2: FYM & $16.60^{\mathrm{abc}}$ & $20.06^{\mathrm{abc}}$ & $18.33^{\mathrm{abc}}$ & $16.86 \mathrm{a}^{\mathrm{bc}}$ & $20.37^{\mathrm{abc}}$ & $18 .^{16 \mathrm{abc}}$ & $17.44^{\mathrm{abc}}$ & $21.07^{\mathrm{abc}}$ & $19.25^{\mathrm{abc}}$ \\
\hline T3: VC & $16.45^{\mathrm{abc}}$ & $19.88^{\mathrm{abc}}$ & $18.16^{\mathrm{abc}}$ & $17.01^{\mathrm{abc}}$ & $20.56^{\mathrm{abc}}$ & $18.33^{\mathrm{abc}}$ & $17.28^{\mathrm{abc}}$ & $20.88^{\mathrm{abc}}$ & $19.08^{\mathrm{abc}}$ \\
\hline T4: PM & $16.56^{\mathrm{abc}}$ & $20.01^{\mathrm{abc}}$ & $18.28^{\mathrm{abc}}$ & $16.97^{\mathrm{abc}}$ & $20.51^{\mathrm{abc}}$ & $18.29^{\mathrm{abc}}$ & $17.40^{\mathrm{abc}}$ & $21.02^{\mathrm{abc}}$ & $19.21^{\mathrm{abc}}$ \\
\hline T5: NC & $16.19^{\mathrm{ab}}$ & $19.56^{\mathrm{ab}}$ & $17.85^{\mathrm{ab}}$ & $16.59^{\mathrm{ab}}$ & $20.05^{\mathrm{ab}}$ & $17.88^{\mathrm{ab}}$ & $17.01^{\mathrm{ab}}$ & $20.55^{\mathrm{ab}}$ & $18.78^{\mathrm{ab}}$ \\
\hline T6: FYM + & $16.70^{\mathrm{bc}}$ & $20.18^{\mathrm{bc}}$ & $18.44^{\mathrm{bc}}$ & $17.12^{\mathrm{bc}}$ & $20.69^{\mathrm{bc}}$ & $18.44^{\mathrm{bc}}$ & $17.55^{\mathrm{bc}}$ & $21.20^{\mathrm{bc}}$ & $19.37^{\mathrm{bc}}$ \\
\hline PM & $16.78^{\mathrm{bc}}$ & $20.27^{\mathrm{bc}}$ & $18.52^{\mathrm{bc}}$ & $17.20^{\mathrm{bc}}$ & $20.78^{\mathrm{bc}}$ & $18.52^{\mathrm{bc}}$ & $17.63^{\mathrm{bc}}$ & $21.30^{\mathrm{bc}}$ & $19.46^{\mathrm{bc}}$ \\
\hline T8: VC + PM & $16.89^{\mathrm{c}}$ & $20.40^{\mathrm{c}}$ & $18.64^{\mathrm{c}}$ & $17.31^{\mathrm{c}}$ & $20.91^{\mathrm{c}}$ & $18.65^{\mathrm{c}}$ & $17.74^{\mathrm{c}}$ & $21.44^{\mathrm{c}}$ & $19.59^{\mathrm{c}}$ \\
\hline T9: VC + NC & $16.64^{\mathrm{bc}}$ & $20.11^{\mathrm{bc}}$ & $18.37^{\mathrm{bc}}$ & $17.06^{\mathrm{bc}}$ & $20.61^{\mathrm{bc}}$ & $18.38^{\mathrm{bc}}$ & $17.49^{\mathrm{bc}}$ & $21.13^{\mathrm{bc}}$ & $19.31^{\mathrm{bc}}$ \\
\hline T10: NC + PM & $16.76^{\mathrm{bc}}$ & $20.25^{\mathrm{bc}}$ & $18.50^{\mathrm{bc}}$ & $17.17^{\mathrm{bc}}$ & $20.75^{\mathrm{bc}}$ & $18.50^{\mathrm{bc}}$ & $17.60^{\mathrm{bc}}$ & $21.27^{\mathrm{bc}}$ & $19.43^{\mathrm{bc}}$ \\
\hline
\end{tabular}

*Mean values with single alphabet are statistically significant

Table.6 Impact of organic manures on Available Potassium $\left(\mathrm{kg} \mathrm{ha}^{-1}\right)$ post-harvest soils

\begin{tabular}{|c|c|c|c|c|c|c|c|c|c|}
\hline $\mathbf{K}$ & \multicolumn{3}{|c|}{ Okra } & \multicolumn{3}{|c|}{ Dhaincha } & \multicolumn{3}{|c|}{ Broccoli } \\
\hline Treatment & 2016 & 2017 & Mean & 2016 & 2017 & Mean & 2016 & 2017 & Mean \\
\hline T1: Control & 237.8 & 234.2 & 236.0 & 236.6 & 233.0 & 234.8 & 235.4 & 231.8 & 233.6 \\
\hline T2: FYM & 233.2 & 229.7 & 231.5 & 232.0 & 228.5 & 230.3 & 230.8 & 227.3 & 229.05 \\
\hline T3: VC & 235.1 & 232.5 & 233.8 & 233.9 & 230.3 & 232.1 & 232.7 & 229.2 & 230.95 \\
\hline T4: PM & 234.8 & 231.3 & 233.1 & 233.6 & 230.1 & 231.9 & 232.5 & 228.9 & 230.7 \\
\hline T5: NC & 234.6 & 231.0 & 232.8 & 233.4 & 229.9 & 231.7 & 232.2 & 228.7 & 230.45 \\
\hline T6: FYM + PM & 233.7 & 230.2 & 232.0 & 232.5 & 229.0 & 230.8 & 231.3 & 227.8 & 229.55 \\
\hline T7: FYM + NC & 234.8 & 231.1 & 233.0 & 233.4 & 229.9 & 231.7 & 232.2 & 228.7 & 230.45 \\
\hline T8: VC + PM & 235.2 & 231.6 & 233.4 & 234.0 & 230.4 & 232.2 & 232.8 & 229.8 & 231.3 \\
\hline T9: VC + NC & 230.7 & 227.2 & 229.0 & 229.6 & 226.1 & 227.9 & 228.4 & 224.9 & 226.65 \\
\hline T10: NC + PM & 234.1 & 230.6 & 232.4 & 232.9 & 229.4 & 231.2 & 231.7 & 228.2 & 229.95 \\
\hline
\end{tabular}

*As per Tukey’s Post-hoc analysis, the values are non-significant 
Table.7 Impact of organic manures on Crop yield of okra $\left(\mathrm{kg} \mathrm{ha}^{-1}\right)$ post-harvest soils

\begin{tabular}{|l|c|c|c|}
\hline \multicolumn{1}{|c|}{ Crop Yield } & & Okra \\
\hline \multicolumn{1}{|c|}{ Treatment } & 2016 & 2017 & Mean \\
\hline T1: Control & $105.87^{\mathrm{a}}$ & $111.03^{\mathrm{a}}$ & $108.45^{\mathrm{a}}$ \\
\hline T2: FYM & $120.86^{\mathrm{b}}$ & $130.67^{\mathrm{b}}$ & $125.77^{\mathrm{b}}$ \\
\hline T3: VC & $131.02^{\mathrm{e}}$ & $133.95^{\mathrm{c}}$ & $132.49^{\mathrm{d}}$ \\
\hline T4: PM & $134.78^{\mathrm{f}}$ & $139.29^{\mathrm{e}}$ & $137.04^{\mathrm{f}}$ \\
\hline T5: NC & $126.52^{\mathrm{c}}$ & $131.06^{\mathrm{b}}$ & $128.80^{\mathrm{c}}$ \\
\hline T6: FYM + PM & $131.08^{\mathrm{e}}$ & $141.02^{\mathrm{e}}$ & $136.06^{\mathrm{ef}}$ \\
\hline T7: FYM + NC & $129.03^{\mathrm{d}}$ & $135.27^{\mathrm{cd}}$ & $132.15^{\mathrm{d}}$ \\
\hline T8: $\mathbf{V C}+\mathbf{P M}$ & $135.49^{\mathrm{f}}$ & $146.32^{\mathrm{f}}$ & $140.91^{\mathrm{g}}$ \\
\hline T9: $\mathbf{V C}+\mathbf{N C}$ & $129.15^{\mathrm{d}}$ & $136.74^{\mathrm{d}}$ & $132.95^{\mathrm{d}}$ \\
\hline T10: $\mathbf{N C}+\mathbf{P M}$ & $131.30^{\mathrm{e}}$ & $139.13^{\mathrm{e}}$ & $135.22^{\mathrm{e}}$ \\
\hline
\end{tabular}

Table.8 Impact of organic manures on Curd Weight of Broccoli (g) post-harvest soils

\begin{tabular}{|l|c|c|c|}
\hline \multicolumn{1}{|c|}{ Curd weight } & Broccoli & & \\
\hline Treatment & $\mathbf{2 0 1 6}$ & $\mathbf{2 0 1 7}$ & Mean \\
\hline T1: Control & $269.33^{\mathrm{a}}$ & $275.66^{\mathrm{a}}$ & $272.50^{\mathrm{a}}$ \\
\hline T2: $\mathbf{F Y M}$ & $282.33^{\mathrm{b}}$ & $292.66^{\mathrm{b}}$ & $287.50^{\mathrm{b}}$ \\
\hline T3: VC & $282.33^{\mathrm{b}}$ & $294.00^{\mathrm{b}}$ & $288.16^{\mathrm{bc}}$ \\
\hline T4: $\mathbf{P M}$ & $289.66^{\mathrm{bc}}$ & $300.33^{\mathrm{bc}}$ & $295.00^{\text {cde }}$ \\
\hline T5: $\mathbf{N C}$ & $283.66^{\mathrm{b}}$ & $293.00^{\mathrm{b}}$ & $288.33^{\mathrm{bc}}$ \\
\hline T6: $\mathbf{F Y M}+\mathbf{P M}$ & $294.00^{\mathrm{c}}$ & $306.66^{\mathrm{c}}$ & $300.33^{\mathrm{e}}$ \\
\hline T7: $\mathbf{F Y M}+\mathbf{N C}$ & $288.00^{\mathrm{bc}}$ & $296.33^{\mathrm{b}}$ & $292.16^{\mathrm{bcd}}$ \\
\hline T8: $\mathbf{V C}+$ PM & $301.66^{\mathrm{d}}$ & $314.33^{\mathrm{d}}$ & $308.00^{\mathrm{f}}$ \\
\hline T9: $\mathbf{V C}+\mathbf{N C}$ & $288.00^{\mathrm{bc}}$ & $296.66^{\mathrm{b}}$ & $292.33^{\mathrm{bcd}}$ \\
\hline T10: $\mathbf{N C}+\mathbf{P M}$ & $291.33^{\mathrm{c}}$ & $306.66^{\mathrm{c}}$ & $299.00^{\mathrm{de}}$ \\
\hline
\end{tabular}

\section{Okra yield and Curd Weight of Broccoli}

During $1^{\text {st }}$ and $2^{\text {nd }}$ year of experiment, significant improvement in crop yield and curd weight was observed in Okra and Broccoli as compared to control (Table $7 \&$ 8 ). The maximum okra yield and curd weight observed was $146.32 \mathrm{q} \mathrm{ha}^{-1}$ in $\mathrm{T}_{8}$ and 314.33 gms in $\mathrm{T}_{8}$ in 2017.

The increase in yield of okra can be attributed to poultry manure application because of its easy solubilization effect of released plant nutrients leading to improved soil physical properties and nutrient status of soil.

The results were in agreement with the findings of Sanwal et al., 2007 in turmeric and Premsekhar and Rajashree 2009 in okra in which credit to higher yield of crops was given to organic manure application thereby improving physical and biological properties of soil resulting in better supply of nutrients to plants.

The yield improvement also confirms the findings of Akande et al., 2003 which 
explained that organic manures has the ability to ameliorate slightly alkaline or acidic soils that will ultimately boost crop yield and related parameters.

The increase in curd weight as compared to control can be attributed to the application of poultry manure and combinations thereby causing an increase in ammonia concentration resulting in immediate and efficient utilization for better curd development.

These results were supported by Chaterjee et al., 2001. The okra yield and broccoli curd weight increased by33.07 and $16.70 \%$.

Higher available nitrogen and phosphorus was observed in soil after the application of organic manures. The same trend was noticed on okra yield and size of curd with the progress in investigation.

The best performing treatment in every parameter was T8 in which the combination of Vermi compost + Poultry Manure was found.

And it is having a great potential to change the dynamics of nutrient and growth with time. So, it can be concluded that the addition of organic manure in vegetable crops can build up the soil fertility over a period of time and the availability of nutrient can be boosted.

The incorporation of dhaincha as source of organic manure can also have a direct impact on soil health and soil productivity with time.

Organic manures thus have a great potential to maintain soil fertility, boost nutrient supply and could contribute to greater food security (Palaniappan, 2000), which also describes organic farming an eco-friendly way to curb climate change and soil lacking quality.

\section{References}

Adekayode, F.O. and M.R. Olojugba, 2010. The utilization of wood ash as manure to reduce the use of mineral fertilizer for improved performance of maize (Zea mays L.) as measured in the chlorophyll content and grain yield. J. Soil Sci. Environ. Manage., 1: 40-45.

Adenawoola AR, Adejoro SA (2005). Residual effects of poultry manure and NPK fertilser residues on soil nutrient and performance of Jute (Corchorusolitorius L). Niger. J. Soil Sci. 15: 133-135.

Ahmed, T., Hafeez, F.Y., Mahmood, T. and Malik, K. (2001).Residual effect of nitrogen fixed by mungbean (Vignaradiata)andblackgram

(Vignamungo) on subsequent rice and wheatcrops.Australian. Expl.Agric.,41: 245-248

Amanullah, M.M., Yassin, M.M., Somasundaram, E., Vaiyapuri,K., Sathyamoorthi, K. and Pazhanivelan, S. (2006). N availabilityin fresh and composted poultry manure.Res. J. Agric. Biol.Sci.,2(6): 406-409.

Babalola, C. A., Adetayo, O.B. and O.L. Lawal Effect of different rates of poultry manure and NPL fertilizer on performance of Celosia argentia.Proc. 20th Annual Conf. of Horticultural Society of Nigeria. Umeh V.C. and Fagbayide (eds.): 2000; 54-56.

Balaguravaiah, D., Adinarayana, G., Prathap, S. and YellamandaReddy, T. (2005). Influence of long-term use of inorganic andorganic manures on soil fertility and sustainable

productivityofrainfedgroudnutinalfisols. J. Indian Soc. Soil Sci.,53(4):606-611.

Barik, A., Das, K. Arindam, Giri, A.K. and Chattopadhyay, G.N.(2006). Effect of organic (Vermicompost, Farm yard manure)and chemical sources of plant nutrients on productivity and soil fertility of Kharif rice (Oryza sativa 
L).Crop Res.,31(3):339-342

Chaterjee, B., Ghanti, P., Thapa, U. and Tripathy, P. 2005. Effect of organic nutrition in sprouting broccoli (Brassica oleracea L var. italicaPlenck). Veg. Sci. 32: 51-54.

Chithesh, C., 2005, Studies on use of organics in tomato (Lycopersiconesculentum Mill.) production. M. Sc (Hort.) Thesis, Univ. Agric.Sci., Dharwad, Karnataka (India)

Dalal, R.C., Strong, W.M., Weston, E.J., Cooper, J.E.,Wildermuth, G.B. , Lehane, K.J., King, A.J. and Holmes, C.J.(1998). Sustaining productivity of a Vertisol at Warra, Queensland, withfertilizers, no-tillage, or legumes, wheatyields, nitrogen benefits and water-use efficiency of chickpea-wheat rotation.Australian J. Expl. Agric.,38: 489-501.

Davis AS, Jacobs DF, Wightman KE (2006). Organic matter amendment of fallow forest tree seedling nursery soils influences soil properties and biomass of sorghum cover crop. Purdue University, West Lafayette, IN.

Dikinya, O. and N. Mufwanzala, 2010. Chicken manure-enhanced soil fertility and productivity: Effects of application rates. J. Soil Sc. Environ. Manage.,1: 46-54.

Doran, J.W. and Parkin, T.B. (1994). Defining and assessing soil quality. In J.W. Doran (Eds.) Defining soil quality for a sustainable environment (pp.3-21). SSSA Special PublicationNo:35, Madison, WI

Elangovan K (1984). Potassium transformation under continuous cropping and fertilization. M. Sc. (Ag) thesis, Tamil Nadu Agric. Univ. Coimbatore, India.

Ghosh,S.c.etal.(1981).J.IndianSoc.SoilSci.,29: 332 336.

Gupta AP, Antil RS, Narwal RP 1988.Effect of farmyard manure on organic carbon, available $\mathrm{N}$, and $\mathrm{P}$ content of soil during different periods of wheat growth. J Indian Soc. Soil Sci. 1988; 262:269273.

Kasikranan, S., 2003. The effects of nutrient supply on the production of commercial baby corn (Zea mays L.) in Thailand. Ph.D. Thesis, Department of Biosciences, University of Hertfordshire, College Lane, Hatfield, Herts, UK.

Larson, W.E. and Clapp, C.E. (1984). Effects of organic matte ron soil physical properties. In properties. In Organic Matter and Rice. Philippines, International Rice Research Institute. Retrieved from http//pdf.usaidgov/pdf_docs/PNAAR18 2.pdf

MO..Akande, J.A. Adediran, and F.I. Oluwatoyinbo,Effects of rock phosphate amended with poultry manure and soil available phosphate. and yield of maize and cowpea,Afri. J. Biotech,4, 2005, 444-448

Moyin-Jesu, E. I. and B. Atoyosoye. 2002. Utilization of Agricultural Wastes for the growth, leaf and soil chemical composition of cocoa seedlings in the nursery. Pertanika Jour. Trop. Agric. Sci. Malaysia 26(1):49-58.

Murwira HK, Kirchmann H (1993). Nitrogen dynamics and maize growth in a Zimbabwean sandy soil under manure fertilization. Commun. Soil Sci. Plant Anal. 24:2343-2359.

Olsen, S.R., Cole, C.V., Watanabe, F.S. and Dean, A.L. (1954).Estimation of available phosphorus in soils by extraction on with Sodium bicarbonate Circular no: 939, USDA.

Pholsen, S., 2003. Effects of nitrogen, potassium and organic matter on growth, chemical components and seed yields of IS 23585 forage sorghum 
cultivar. Ph.D. Thesis. University of Hertfordshire, Collage Lane, Hatfield, Herts, UK.

Pilbeam, C.J., Wood, M., Harris, H.C. and Tuladhar, J. (1998).Productivity and nitrogen use of three different wheatbasedrotations in northwest Syria.Aust. J. Agric. Res.,49: 451-458.

Piper, C.S. (1966).Soil and Plant Analysis. Inter Science Publications. New York

Prasanthrajan, M., Doraisamy, P. and Kannan, J. (2008).Influence of organic amendments on soil microbial enzymeactivity and available nitrogen release pattern.J. Ecobiol.,22(1): 57-62.

Premsekhar, M. and Rajashree,V. (2009). Influenceof organic manure on growth, yield and quality of okra. American Eurasian Journal of Sustainable Agriculture,3(1):6 -8.

Sa' nchez-Dí az, M., García, J.L., Antolín, M.C., Araus, J.L., 2002.Effects of soil drought and atmospheric humidity on yield, gasexchange, and stable carbon isotope composition of barley.Photosynthetica 40, 415-421.

Sanwal, S.K., Lakminarayana,K., Yadav, R.K. Rai, N.,Yaldav,D.S. and Mousumi,B. (2007). Effect of organic manures on soil fertility, growth, physiology, yield and quality of turmeric. Indian Journal of Horticulture.64(4): $444-449$.

Savoshi, M., Nasiri, A., and Laware, S.L. (2011). Effect of organic fertilizer on growth and yield component in rice $\mathrm{J}$. Agric. Sci.,3(3) : 217-224.

Simek, M., Hopkins, D.W., Kalcík, J., Picek, T., Santrucko-va, H., Stana,J. andTravník, K. (1999). Biological and chemical properties of arable soils affected by long-term organic and inorganic fertilizer applications. Biol. Fertil. Soils, 29: 300-308.

Son TTN and PP Ramaswami 1997. Bioconversion of organic wastes for sustainable agriculture. OMON RICE. (5): 56 - 61 .

Stanford, G. and English, L. (1949). Use of flame photometer in rapid soil test for $\mathrm{K}$ and Ca. Agron. J.,41: 446

Subbiah, B.V. and Asija, G.L. (1956). A rapid procedure for estimation of available nitrogen in soils. Curr. Sci.,25: 259-260

Sudha, B. and Chandini, S. (2003). Vermicompost - potential organic manure for rice. Intensive Agriculture, pp.23-29.

Sudhakar, G. (2000). Studies on to identify crop wastes / lowland weeds as alternate source to organics to sustain the productivity of rice based system. Ph.D. Thesis, Tamil Nadu Agricultural University, Coimbatore, T.N. (India).

Walkley, A. and Black, C.A. (1934). An examination of the Degtjareff method for determining soil organic matter and a proposed modification of the chromic acid titration method

\section{How to cite this article:}

Vishaw Vikas, A.K. Mondal, Vikas Sharma and Jag Paul Sharma. 2020. Soil Nutrient and Crop Growth Dynamics in Organically Managed Cropping System. Int.J.Curr.Microbiol.App.Sci. 9(02): 40-50. doi: https://doi.org/10.20546/ijcmas.2020.902.007 